\title{
KURIKULUM 2013 DALAM PERSPEKTIF FILSAFAT PENDIDIKAN PROGRESIVISME
}

\section{Curriculum 2013 Based on The Philosophy Perspective of Progressivism}

\author{
Ika Nurma Noviyanti ${ }^{{ }^{*}}$ \\ 1Universitas Muhammadiyah Surakarta, Indonesia \\ *Email: ikanurma95@gmail.com
}

\begin{abstract}
Abstrak: Perlu dipahami bahwa kurikulum adalah jantung pendidikan. Kurikulum pendidikan di Indonesia sudah mengalami berbagai pergantian yang di dasarkan pada penyempurnaan kurikulum sebelumnya begitu juga dengan Kurikulum 2013 yang menyemprnakan kurikulum sebelumnya. Landasan filsafat yang digunakan dalam merancang kurikulum sangatlah penting guna menentukan tujuan pendidikan. Hasil dari penelitian bahwa Kurikulum 2013 dapat meningkatkan perubahan pengetahuan, sikap, dan keterampilan terhadap peserta didik untuk terwujudnya pendidikan karakter yang lebih baik. Kurikulum 2013 memiliki sebuah tujuan yaitu melahirkan generasi aktif, inovatif dan kreatif yang bertujuan mampu mengurangi kebodohan, kemiskinan, dan keterbelakangan kehidupan. Kurikulum 2013 mempunyai landasan filsafat yang mengadopsi filsafat asing atau disebut dengan eklektik inkorporatif kemudian disinkronkan dengan sistem pendidikan nasional Indonesia. Progresivisme adalah aliran filsafat pendidikan yang menitik beratkan pada sebuah proses, dimana Kurikulum 2013 secara teori lebih menitik beratkan pada peserta didik. Kurikulum 2013 menggambarkan jika peserta didik harus mendapatkan pembelajaran yang sesuai dengan berkembangnya zaman agar melahirkan generasi pembaharu dan setiap kompetensi pada peserta didik dinilai secara menyeluruh baik pengetahuan, sikap, dan keterampilan.
\end{abstract}

\section{Kata kunci : Kurikulum 2013, Progresivisme, Filsafat pendidikan}

Abstract: It should be understood that curriculum is the heart of education. The education curriculum in Indonesia has undergone various changes which are based on refining the previous curriculum as well as the 2013 Curriculum which synchronizes the previous curriculum. The philosophical foundation used in designing the curriculum is very important in determining educational goals. The results of the research show that the 2013 Curriculum can increase changes in knowledge, attitudes, and skills towards students for the realization of better character education. The 2013 curriculum has a goal of giving birth to an active, innovative and creative generation that aims to reduce ignorance, poverty and underdevelopment in life. The 2013 curriculum has a philosophical basis that adopts a foreign philosophy or is called an inclusive eclectic which is then synchronized with the Indonesian national education system. Progressivism is an educational philosophy that focuses on a process, where the 2013 Curriculum in theory focuses more on students. The 2013 curriculum illustrates if students must get learning that is in accordance with the development of the times in order to give birth to a generation of reformers and every competency in students is assessed as a whole both knowledge, attitudes, and skills.

Keywords : Curriculum 2013, Progressivism, Educational philosophy 


\section{PENDAHULUAN}

Pendidikan adalah proses memanusiakan manusia agar manusia menjadi lebih manusiawi. Nilai kemanusiaan adalah tujuan sebuah pendidikan baik dari segi kepribadian, keterampilan, dan kepatuhan terhadap sang Pencipta. Nilai yang dimaksud adalah kesiapan seseorang untuk menyerahkan diri dan patuh terhadap sang Pencipta. Pendidikan merupakan hal yang krusial bagi keberlangsungan hidup manusia di masa mendatang. Oleh karena itu, bidang pendidikan harus diarahkan untuk mendapatkan hasil yang unggul dan diperlukan kesiapan berbagai bidang agar bangsa Indonesia tidak dimangsa oleh negara lain. Dalam dunia pendidikan juga dikenal istilah kurikulum, kurikulum ialah program pembelajaran dan pengajaran yang dilandasi oleh sebuah lembaga pendidikan dengan rancangan pembelajaran yang dikenakan kepada anak didik dalam kurun waktu tertentu guna mencapai sebuah tujuan tertentu. Kurikulum mempunyai banyak fungsi yang diantaranya sebagai sarana mencapai tujuan pendidikan nasional.

Setelah kemerdekaan kurikulum pendidikan Indoneesia sudah mengalami perubahan yaitu sebanyak 11 kali, diantaranya pada tahun 1947, 1952, 1964, 1968, 1975, 1984, 1994, 2004, 2006, 2013, dan 2015. Pergantian kurikulum merupakan imbas perubahan sistem pemerintahan, sosial budaya, politik, iptek, dan ekonomi dalam kehidupan masyarakat. Pergantian kurikulum diduga merupakan alasan banyak terjadinya permasalahan di dunia pendidikan. Kurikulum yang sekarang digunakan ialah kurikulum 2013 atau Kurtilas. Kurikulum 2013 dirancang agar siswa aktif dalam proses pembelajaran dan guru senantiasa sebagai fasilitator.

Kurikulum 2013 pada dasarnya sangat bagus hanya saja persoalan menyangkut Kurikulum 2013 banyak. Ketua PB PGRI (Pengurus Besar Persatuan Guru Republik Indonesia) Sulistyo, mengatakan peraturan yang dikeluarkan pemerintah guna mewujudkan kurikulum yang berlandaskan observasi integratif dinilai mengesampingkan kesiapan guru. Masih banyak guru yang belum menguasai konsep dari Kurikulum 2013. Masyarakat menganggap bahwa pemerintah tidak memperhatikan kondisi kesetaraan guru yang paling utama guru di daerah pedalaman dimana dengan tidak gampang beradaptasi dengan sesuatu yang asing pada waktu yang cepat (Kedaulatan Rakyat, 25 Januari 2013). Sejalan dengan hal tersebut Murodah (2019) dalam penelitiannya mengatakan bahwa guru belum mempunyai bekal yang cukup serta pelaksanaannya belum ada persiapan yang matang dalam menjalankan Kurikulum 2013. Berbanding terbalik, penelitian yang dilakukan oleh Kristiantari (2014) bahwa secara teori guru telah mempunyai pemahaman mengenai Kurikulum 2013, akan tetapi masih mengalami kendalaa dalam mengaplikasikannya. Mengingat pentingnya kurikulum di dunia pendidikan, dengan demikian kurikulum harus dibuat dan dilakukan dengan baik. Artinya, kurikulum bisa dikembangkan menuju yang lebih baik dengan mempertimbangkan sumber daya manusianya. 
Berdasarkan uraian di atas, terdapat aliran filsafat yang sejalan dengan dikehendakinya perubahan di dunia pendidikan. Aliran filsafat pendidikan yang dimaksud yakni aliran filsafat progresivisme dimana suatu aliran filsafat yang menginginkan adanya perbaikan untuk sebuah pembaharuan atau perubahan.

\section{METODE PENELITIAN}

Penelitian ini dilakukan menggunakan metode studi pustaka (library research). Data yang dipakai merupakan data sekunder berupa buku, artikel jurnal serta proccedings konferensi yang berkaitan dengan judul penelitian. Prosedur analisis data dimulai dengan mengumpulkan referensi yang berkaitan dengan Kurikulum 2013 berdasarkan paham progresivisme. Data yang diperoleh kemudian dianalisis dan dikaji untuk mendapatkan informasi berkaitan dengan judul yang diangkat oleh penulis. Hasil analisis yang didapat diselaraskan dengan judul yang ditulis oleh penulis.

\section{HASIL DAN PEMBAHASAN}

\section{Kurikulum 2013}

Kurikulum 2013 merupakan kurikulum penyempurna bagi kurikulum sebelumnya. Perubahan Kurikulum 2013 didasarkan kepada standar kompetensi lulusan, materi, proses dan penilaian komperhensif. Pemaparan perubahan dalam kurikulum 2013 (Kemendikbud, 2013: 119) yaitu: (1) Kompetensi Lulusan: Dibangun secara holistic, aspek pendidikan yang mendukung, dan pembauran secara menyeluruh. (2) Materi: Menggnakan basis kompetensi sehingga semua aspek terpenuhi, dapat memfasilitasi media lokal, nasional dan internasional. (3) Proses: a) Berpusat pada standar kompetensi: 1) Sikap: menghargai, menerima, mengamalkan, dan menjalankan. 2) Keterampilan: mengamati, mencoba, menalar, menanya, menyajikan, dan mencipta. 3) Pengetahuan: memahami, mengetahui, menganalisis, menerapkan, mengevaluasi, dan mencipta. b) Menggunakan pendekatan scientifik karakteristik, karakteristik kompetensi sesuai jenjang (SD: tematik terpadu, SMP: tematik terpadu IPA/IPS dan mata pelajaran, SMA: tematik dan mata pelajaran). c) Diutamakan discovery learning dan project-based learning. (4) Penilaian: a) Berdasarkan tes dan non tes (porfolio). b) Penilaian menggunakan penilaian autentik (mengukur tingkat berpikir dari rendah hingga tinggi dan proses kerja siswa). c) Nilai rapor menggunakan penilaian kuantitatif (pengetahuan) dan penilaian deskripsi kualitatif (keterampilan dan sikap).

Faris (2015) dalam penelitiannya mengatakan bahwa kurikulum mengharapkan perubahan secara keseluruhan dalam dunia pendidikan. Pendidikan merupakan alat yang dapat menbentuk manusia menjadi pribadi yang lebih baik. Kurikulum 2013 menginginkan peserta didik berpikir secara konkret dan memiliki kemampuan kecerdasan yang dapat mewadahi. Tolak ukur kecerdasan diukur dari 
kemampuan peserta didik dalam mengingat materi pelajaran dalam berbagai disiplin ilmu, baik dalam ilmu pengetahuan alam, ilmu humaniora, dan ilmu pengetahuan social. (Muhammad, 2014). Sedangkan menurut Yunus (2016) kurikulum memiliki kedudukan yang krusial sebagai jantung pendidikan, tidak hanya sebagai perangkat pembelajaran yang dibuat untuk disajikan di sebuah institusi pendidikan, namun juga mempunyai makna yang luas. Kurikulum 2013 dirancang dengan kepercayaan diri tinggi guna melahirkan peserta didik yang kreatif, inovatif, cerdas, dan mempunyai kepercayaan diri tinggi serta memiliki sikap toleransi (Murodah, 2019).

\section{Landasan Filsafat Kurikulum 2013}

Orsntein dan Hunkins (Muhammad, 2014) Kurikulum 2013 berlandaskan filsafat idealisme mempunyai hakikat bahwa moral, mental, dan realitas spiritual memiliki sifat yang tidak berubah. Perilaku moral, mental, dan agama dari dahulu hingga sekarang tetap sama. Dalam unsur keagamaan, Kurikulum 2013 mendorong adanya pengakuan hukum agama serta mengaplikasikan di dalam keseharian. Dalam unsur keagamaan, Kurikulum 2013 menitik beratkan pada doktrin agama (religious doctrine) untuk bimbingan hidup (religious guidance). Ilmu agama didalami pada unsur hukum untuk diaplikasikan dalam keseharian sebagai kehidupan yang beragama (living religion). Contoh hukum ajaran Islam yaitu puasa, shalat, dan zakat dipelajari serta diaplikasikan dalam keseharian.

Secara epistemologis, Kurikulum 2013 mendaur ulang pemikiran yang tersembunyi. Pemikiran tersembunyi itu adalah pemikiran besar dalam berbagai ajaran ilmu pengetahuan diantaranya: Bidang ilmu pengetahuan alam seperti kimia, fisika, biologi, geologi, astronomi, dan kedokteran. Bidang ilmu pengetahuan sosial seperti ilmu pendidikan sosiologi, hukum, antropologi, ilmu politik, psikologi, dan ekonomi. Bidang ilmu humaniora yang terdiri dari matematika, filsafat, seni, dan teologi. Menurut salah satu aliran filsafat pendidikan yaitu perenialisme, tujuan dar sebuah pendidikan ialah membentuk peserta didik agar berpikir rasional dan memiliki kapasitas kecerdasan yang mempuni. Guru ialah orang yang memiliki kemampuan akademik ilmiah dan dapat menyampaikan materi pembelajaran yang bersifat permanen, meliputi ilmu sosial seperti ilmu ekonomi, sosiologi, ilmu sejarah, antropologi, ilmu alam seperti ilmu biologi, ilmu kimia, ilmu fisika dan ilmu humaniora seperti teologi.

Sedangkan menurut salah satu aliran filsafat pendidikan yaitu esensialisme, pengetahuan bisa berbentuk kemampuan dasar akademik, prinsip, dan konsep serta teori-teori ilmiah pada berbagai disiplin ilmu. Guru mengajarkan banyak pengetahuan, sikap, dan nilai tradisional. Guru sebagai orang yang mempunyai kemampuan keilmuan pada bidang ilmu tertentu. Guru juga dianggap sebgai orang yang sudah melalui proses pendidikan dalam jangka panjang sebelum memiliki jabatan sebagai seorang pendidik. 
Menurut Permendikbud Nomor 68 Tahun 2013 (Kerangka Dasar Kurikulum 2013, Permendikbud Nomor 68, 2013: 5) landasan filsafat kurikulum 2013 adalah sebagai berikut: (1) Berlandaskan budaya bangsa dalam membangun kehidupan yang baru sesuai dengan berkembangnya zaman. (2) Subjek didik adalah ahli waris budaya bangsa. (3) Pendidikan bertujuan membentuk kecerdasan intelektual dan akademik melalui pendidikan berbagai bidang ilmu. (4) Alat untuk menciptakan kehidupan yang lebih baik sesuai dengan berkembangnya zaman berdasarkan kemampuan berkomunikasi, kemampuan intelektual, kepedulian, sikap sosial, serta berpartisipasi dalam menciptakan kehidupan yang lebih baik.

\section{Aliran Progresivisme}

Progresivisme sendiri berasal dari kata progresif memiliki arti maju. Kata progresif bisa tafsirkan sebagai arah menuju kemajuan, berarah pada kebaikan, dan menjadi baik. Dapat diartikan bahwa progresif adalah suatu perbuatan yang menuju ke arah perbaikan. Progresivisme ialah aliran filsafat yang menghedaki adanya perbaikan menuju ke arah yang lebih baik. Gutek (Mutmainnah, 2020) progresivisme menitik beratkan pada kata "progress"e bahwasanya manusia mempunyai kemampuan untuk menjadikan lingkungannya menjadi lebih baik dengan mengaplikasikan kecerdasan yang dimilikinya dalam menyelesaikan permasalahan yang timbul baik dalam kehidupan pribadi maupun kehidupan sosial. Pendidikan progresivisme merupakan teori pembelajaran yang mengutamakan kebebasan dan kemerdekaan peserta didik dari tekanan pembelajaran yang bersifat dikte dan hafalan terhadap buku teks (Musyarapah, 2017).

Aliran progresivisme lahir sekitar abad ke 20 yang di latar belakangi oleh ketidakpuasan terhadap pendidikan yang masih tradisional, otoriter dan siswa dijadikan objek pembelajaran bukan subyek didik. Pendapat lain mengatakan aliran progresivisme secara sejarah sudah ada pada abad ke 19, akan tetapi keberadaannya terlihat di abad ke 20, khususnya Amerika Serikat (Muhmidayeli, 2012). Aliran filsafat progresivisme ingin mengembangkan asas kemajuan dalam semua keadaan terutama kehidupan untuk tetap bertahan terhadap tantangan hidup yang dihadapi. Pemikiran yang berdampak pada perkembangan aliran progresivisme antara lain yaitu pemikiran John Dewey, Johan Heinrich Pestalozzi, dan Sigmund Freud. Pemikiran yang lahir dari mereka merupakan inspirasi bagi aliran progresivisme.

Menurut Mutmainnah (2020) aliran progresivisme ialah aliran filsafat pendidikan yang menginginkan adanya sebuah perubahan instan ke arah yang lebih baik. Pendidikan bisa membawa sebuah perbaikan pada peserta didik untuk menjadi karakter yang lebih kuat dan dapat menghadapi berbagai permasalahan serta bisa beradaptasi dalam kehidupan sosial maupun bermasyarakat.

\section{Kurikulum Pendidikan Progresivisme}

Dalam sudut pandang progresivisme, kurikulum adalah seperangkat rancangan pembelajaran yang bisa merubah peserta didik secara praktis, baik di sekolah maupun di masyarakat. Kurikulum dalam 
sudut pandang progresivisme merupakan pembelajaran yang bersifat eksperimental, memiliki rencana serta susunan yang teratur (Amir Ma'ruf dalam Muhammad, 2017). Aliran progresivisme menginginkan kurikulum menitik beratkan pada pengalaman berdasarkan interaksi antara manusia dengan lingkungan sekitarnya (Jalaluddin \& Abdullah Idi, 2012: 91). Akan tetapi, pada konteks ini progresivisme menginginkan tidak ada mata pelajaran yang diberikan tidak dalam waktu bersamaan. Artinya, mata pelajaran yang diberikan harus bersamaan tidak terpisah.

Senada dengan uraian tersebut, Kilpatrick (Jalaluddin \& Abdullah Idi, 2012: 93) berpendapat bahwa kurikulum dikatakan baik jika berlandaskan tiga prinsip, yaitu: (1) Kesejahteraan peserta didik ditingkatkan. (2) Kehidupan baru peserta didik berkembang secara menyeluruh. (3) Mengembangkan aspek kreatif peserta didik sebagai uji coba keberhasilan sekolah.

Dalam merealisasikan prinsip tersebut, Kilpatrick menjelaskan, sebagai berikut: (1) Kurikulum meningkatkan kualitas hidup berdasarkan jenjang pendidikan. (2) Kurikulum mampu meningkatkan potensi peserta didik. (3) Kurikulum dapat mempengaruhi tingkah laku peserta didik menjadi lebih baik. (4) Kurikulum bersifat fleksibel. Penjelasan di atas adalah karakteristik kurikulum menurut aliran filsafat pendidikan progresivisme. Artinya, kurikulum harus bekerja sama dalam menyikapi permasalahan yang ada, baik di masyarakat dengan model pembelajaran maupun praktik, dan menggunakan metode problem solving dalam proses pembelajaran.

\section{Kekurangan dan Kelebihan Kurikulum 2013 Menurut Aliran Progresivisme}

Kurikulum 2013 adalah awal dari terbentuknya tujuan pendidikan nasional. Tujuan pendidikan nasional mengharapkan manusia agar berakhlak mulia, bertakwa, dan beriman, berilmu, sehat, cakap, demokratis, mandiri, bertanggungjawab, dan kreatif. Filsafat pendidikan yang hadir sebagai landasan kurikulum yaitu rekonstruksivisme, perennialisme, progressivisme, eksperimentalisme, dan essensialisme. Kurikulum 2013 sendiri menggunakan landasan filsafat yang mengadopsi filsafat asing atau disebut dengan eklektik inkorporatif kemudian disinkronkan dengan sistem pendidikan nasional Indonesia. Adapun kekurangan dan kelebihan Kurikulum 2013, sebahai berikut: (a) Kelebihan: 1) Ide Kurikulum: Berlandaskan budaya untuk kehidupan dimasa yang akan datang. 2) Isi Kurikulum: Kompetensi dasar dan kompetensi inti sesuai dengan lingkungan hidup peserta didik. 3) Pembelajaran: Menitik beratkan aplikasi yang menyangkut kehidupan dan menitik beratkan kemampuan produktif, kreatif, serta berpikir kritis yang dapat mempengaruhi kualitas peserta didik. 4) Penilaian hasil akhir: Menitik beratkan kemampuan pengetahuan, keterampilan dan sikap. (b) Kekurangan: 1) Ide Kurikulum: Menggabungkan landasan filsafat pendidikan perennialisme dan progressivisme. 2) Isi Kurikulum: Mengharapkan subyek didik sesuai dengan kompetensi bukan hal yang mudah dan bukan hal yang tidak mungkin dan Kurikulum 2013 ingin melahirkan subyek didik yang kompeten. 3) Pembelajaran: 
Kurikulum harus sesuai dengan kebutuhan subyek didik dan guru juga harus tahu kualitas dan potensi subyek didik. 4) Penilaian hasil akhir: Penilaian pada subyek didik bukan lagi pada rentang angka, penilaian hendaknya bersifat kualitatif dan deskriptif., serta guru menilai subyek didik atas tiga hal yakni pengetahuan, keterampilan, dan sikap.

Sumbangsih Aliran Progresivisme Terhadap Kurikulum 2013

Aliran progresivisme meberikan subangsih yang cukup besar terhadap perkembangan Kurikulum 2013. Pandangan progresivisme yang demokratis dengan mengutamakan peserta didik memberikan pembaharuan dalam dunia pendidikan dengan peserta didik sebagai pusat pembelajaran. Pendidikan untuk peserta didik ialah pendidikan yang mengasyikan serta tidak membosankan. (a) Anak sebagai subjek didik, progresivisme berpusat pada perkembangan peserta didik dimana pendidikan harus memenuhi tumbuh kembang peserta didik. Perkembangan peserta didik didasarkan pada minat dan bakat, dimana peserta didik menjadi subjek didik yang sebenarnya. Keinginan dan kebutuhan peserta didik harus difasilitasi untuk mencapai minat dan bakatnya. Progresivisme memberikan kejelasan pada sistem pendidikan Kurikulum 2013. Peserta didik tidak merasa terkekang dalam proses pembelajaran akan tetapi lebih bersifat fleksibel dalam menggunakan waktu di sekolah. Peserta didik dengan leluasa dapat mengekspresikan dirinya dalam dunia nyata baik terhadap dirinya sendiri maupun lingkungan disekitarnya. (b) Peran guru sebagai fasilitator, dalam aliran filsafat progresivisme guru berperan sebagai fasilitator bukan seseorang yang berlaku otoriter. Guru diharuskan dapat memahami siswa baik secara pengetahuan, keterampilan, dan sikap. Guru melakukan pembelajaran berdasarkan bagaimana peserta didik berpikir. (c) Kurikulum yang terintegrasi, kurikulum dipandang baik jika menggambarkan karakter masyarakatnya. Kurikulum dapat meningkatkan kemampuan dan minat seseorang sehingga seseorang dapat berperan aktif, baik di sekolah maupun di masyarakat. Kurikulum yang diharapkan aliran progresivisme yaitu bersifat utuh dan menyeluruh antara pengetahuan, keterampilan, dan sikap. Kurikulum 2013 menggunakan tematik terpadu agar terbentuk keselarasan antar jenjang pendidikan. Kontribusi yang diperoleh Kurikulum 2013 dari metode tematik terpadu ialah sebagai berikut: (1) Guru percaya bahwa peserta didik melihat dunia sebagai keutuhan yang terhubung. (2) Keterkaitan pada mata pelajaran memperkuat pembelajaran peserta didik sehingga proses pembelajaran bersifat konvergen. (3) Kompetensi dari mata pelajaran dijadikan satu secara utuh sehinggga dapat dipelajari secara mendalam. Menurut Anshory et al. (2018) dalam penelitiannya mengatakan pembelajaran tematik terpadu mengkoordinir anak didik dalam meningkatkan kemampuan berpikir tingkat tinggi dengan memaksimalkan kecerdasan ganda sehingga potensi keterampilan, pengetahuan, dan sikap bisa berkembang. Pembelajaran tematik terpadu berpusat pada pengaplikasian pembelajaran yang selaras dengan perkembangan dan kebutuhan anak didik. Sedangkan menurut Hidayani (2016) pembelajaran 
tematik merupakan sarana pembelajaran yang berdasarkan kompetensi dimana pembelajaran akan menggunakan tema agar memudahkan subyek didik memahami informasi baru yang diperoleh dan akan menghubungkan antar konsep guna menghasilkan suatu pemahaman yang utuh. (d) Memunculkan pendidikan karakter, progresivisme mengembangkan pendidikan karakter dalam proses berpikirnya. Peserta didik menjadi pelaku utama di bidang pendidikan. Proses pendidikan yang menekankan pada perkembangan peserta didik secara berkelanjutan akan memunculkan pribadi yang kuat dalam jiwa peserta didik. Menurut Kusumawati (2016) pendidikan karakter ialah usaha sadar dan terencana untuk meningkatkan potensi peserta didik secara menyeluruh serta mengajarkan kebiasaan baik terhadap peserta didik, sehingga mampu menjadi kebiasan yang baik dalam kehidupan bermasyarakat. Pendidikan karakter sering disebut sebagai pendidikan budi pekerti dimana nilai moralitas manusia diwujudkan dalam aksi nyata. Nilai moralitas yang diwujudkan menjadikan manusia pribadi yang baik dan manusiawi. Karakter yang dibentuk merupakan karakter manusia yang bersifat baik bukan buruk. Pendidikan karakter ialah jati diri Kurikulum 2013 yang mengharapkan pembaharuan kualitas manusia dari segi pengetahuan, keterampilan, dan sikap. Pendidikan adalah wadah yang tepat untuk meningkatkan pembentukan karakter. (e) Pemahaman mengenai pengembangan kurikulum, Kurikulum dapat diartikan sebagai jantung pendidikan. Pendidikan dalam segi proses selalu mengalami perubahan karena ilmu pengetahuan selalu berubah seiring dengan perkembangan zaman. Perubahan kurikulum adalah hal yang wajar sebagai dampak dari perubahan sistem pemerintahan, politik, ekonomi, sosial, dan budaya. Perubahan kurikulum juga sebagai bentuk penyempurnaan dari kurikulum-kurikulum sebelumnya.

\section{SIMPULAN DAN SARAN}

Kurikulum pendidikan Indonesia sudah mengalami beberapa kali pergantian sebagai dasar untuk menyempurnakan setiap kurikulum yang sudah ada. Kurikulum 2013 menitik beratkan pada perkembangan peserta didik. Tujuan Kurikulum 2013 ialah meningkatkan perubahan dalam segi pengetahuan, keterampilan, dan sikap. Kompetensi (pengetahuan, sikap, dan keterampilan) dinilai secara menyeluruh dan utuh agar melahirkan generasi pembaharu sehingga kebodohan, kemiskinan, dan keterbelakangan kehidupan dapat berkurang. Kurikulum 2013 mempunyai landasan filsafat yang mengadopsi filsafat asing atau disebut dengan eklektik inkorporatif kemudian disinkronkan dengan sistem pendidikan nasional Indonesia. Progresivisme adalah aliran filsafat pendidikan yang menitik beratkan pada sebuah proses, dimana Kurikulum 2013 secara teori lebih menitik beratkan pada peserta didik. Kurikulum 2013 menggambarkan jika peserta didik harus mendapatkan pembelajaran yang sesuai dengan berkembangnya zaman agar melahirkan generasi pembaharu dan setiap kompetensi pada peserta didik dinilai secara menyeluruh baik pengetahuan, sikap, dan keterampilan. Kurikulum 2013 pada 
dasarnya sudah bagus hanya saja untuk pengaplikasikannnya pemerintah lebih memperhatikan lagi kesetaraan kondisi guru karena guru yang tinggal di kota dengan pedalaman akan mempunyai permasalahan yang berbeda, begitu pun dalam persiapan Kurikulum 2013 harus disiapkan dengan matang agar tidak ada lagi guru yang tidak paham mengenai konsep Kurikulum 2013. Sebelum pelaksanaan sebaiknya guru diberikan workshop mengenai Kurikulum 2013.

\section{REFERENSI}

Anshory, I., Saputra, Y.S., \& Amelia, J.D. (2018). Pembelajaran tematik integratif pada kurikulum 2013 di kelas rendah SD Muhammadiyah 07 Wajak. Jurnal Inovasi Pendidikan. 4(1), 35-46.

Fadillah, M. (2017). Aliran progresivisme dalam pendidikan Indonesia. Jurnal Dimensi Pendidikan dan Pembelajaran. 5(1), 17-24

Faris, A.F. (2015). Kurikulum 2013 dalam perspektif filsafat pendidikan progresivisme. Jurnal Filsafat. 25(2), 317-337.

Hanif, M. (2014). Tinjauan filosofis kurikulum 2013. Isnania. 19(1), 87-114.

Hidayani, M. (2016). Pembelajaran tematik dalam kurikulum 2013. At-Ta 'lim. 15(1), 150-165.

Jalaluddin dan Abdullah Idi. (2012). Filsafat Pendidikan; Manusia, Filsafat dan Pendidikan. Jakarta: Rajawali Press.

Kedaulatan Rakyat. (2013). Kurikulum 2013. 25 Januari 2013.

Kementrian Pendidikan dan Kebudayaan. (2013). Draft Implementasi Kurikulum 2013: Jakarta.

Kristiantari, R.M. (2014). Analisis kesiapan guru sekolah dasar dalam mengimplementasikan pembelajaran tematik integratif menyongsong kurikulum 2013. Jurnal Pendidikan Indonesia. $3(2), 460-470$.

Kusumawati, I. (2016). Landasan filosofis pengembangan karakter dalam pembentukan karakter. Academy of Education Journal. 7(1), 1-15.

Maimunnah. (2020). Pemikiran progresivisme dan eksistensialisme pada pendidikan anak usia dini. Internasiol Journal of Child and Gender Studies. 6(1), 13-26.

Muhmidayeli. (2012). Filsafat Pendidikan. Bandung: Refika Aditama

Murodah, N. (2019). Pengembangan kurikulum: kajian atas pemahaman dan kesiapan guru madrasah dalam melaksanakan kurikulum 2013. Jurnal Studi Keislaman. 5(1), 94-112.

Musyarapah. (2017). The role of progressive philosophy in the curriculum based on john dewey's theory. Al-hayat. 1(1), 32-39.

Yunus, A.H. (2016). Telaah aliran pendidikan progresivisme dan esensialisme dalam perspektif filsafat Pendidikan. Jurnal Cakrawala Pendas. 2(1), 29-39. 